\title{
Preliminary Design, Drive-Cycle Simulation and Energy Analysis of a Hybrid Transit Bus
}

\author{
Roberto Capata \\ Department of Mechanical \& Aerospace Engineering, University Roma Sapienza, Roma 00184, Italy
}

\begin{abstract}
Modern metropolises are increasingly affected by air quality problems. Transportation is one of the largest sources of several pollutants emissions, such as nitrogen oxides $\left(\mathrm{NO}_{\mathrm{x}}\right)$ and carbon monoxide $(\mathrm{CO})$. Today in the EU, vehicles' emissions are strictly limited by Euro 6 norm-Euro VI for heavy-duty vehicles—which is periodically upgraded. To match such limits, manufacturers are forced in developing new technologies to perform new sustainable vehicles design strategies, such as EVs and HEVs. Present work's aim is to provide the design of series-hybrid urban transportation bus, equipped with a novel thermal power unit, namely a small gas turbine, to exploit its cleaner combustion process in comparison with an ICE. The control logic is described, while the main drivetrain components are chosen, and suitable models from suppliers are selected as well. Then, some simulations of the resulting vehicle are performed on opportune drive cycles, using Advisor, a free software based on Matlab-Simulink environment, published by US' National Renewable Energy Laboratory (NREL). Two different final configurations are environmentally and economically analysed, with the thermal power unit being respectively fuelled by compressed natural gas (CNG) and liquefied petroleum gas (LPG). Both satisfy the Euro VI norms, showing a substantial emission reduction (-89\% and $-43 \%$ in $\mathrm{CO}$ and $\mathrm{THC}$ releases respectively) in comparison to pollutants' threshold values.
\end{abstract}

Key words: HEV, GTHV, heavy-duty, bus, Advisor, microturbine (MT), gas turbine (GT), CNG, LPG, simulation, drive cycle, Euro VI, WHTC, emissions, NOx, CO, THC, sustainability, pollution.

\section{Introduction}

The present paper has the purpose to provide the design and drive-cycle simulation of a hybrid urban transit bus, to quantitatively determine how much emission would be saved within the Euro VI boundaries. Moreover, an economic analysis of the designed drivetrain impact is performed in terms of fuel consumption and transport costs, in comparison with two traditional diesel-ICE analogues vehicles.

This work is developed in conjunction with the Department of Mechanical and Aerospace Engineering of "Sapienza" University of Rome, Italy, and it takes its origins from several previous studies, cited in the GTHV configuration paragraph.

Corresponding author: Roberto Capata, Ph.D., senior researcher, research fields: UMGT, hybrid vehicles, ORC expanders, reciprocating machinery, energy systems analysis and diagnosis.

\subsection{Pollution by Road Transport Sector}

Air pollution is the chemical alteration of atmosphere. It results from the release of compounds that are not included in air natural composition, as well as species that are commonly included in atmospheric gaseous mix but in different quantities. Emissions reduction theme is one of the biggest challenges of our era [1-4], and it is a priority point of automotive industry. Transportation sector is one of the major responsible in air pollution, especially when referred to big cities areas. It is possible to observe from Fig. 1 how large is its impact on each pollution agent of total emissions. Road transport sector results to be the heavier in $\mathrm{NO}_{\mathrm{x}}$ emissions with about $40 \%$ of total, and the second in $\mathrm{CO}$ and PM2.5 releases with respective approximate shares of $20 \%$ and $10 \%$.

\section{$1.2 \mathrm{NO}_{x}$ Issue}

Nitrogen oxides $\left(\mathrm{NO}_{\mathrm{x}}\right)$ released in exhausts from 


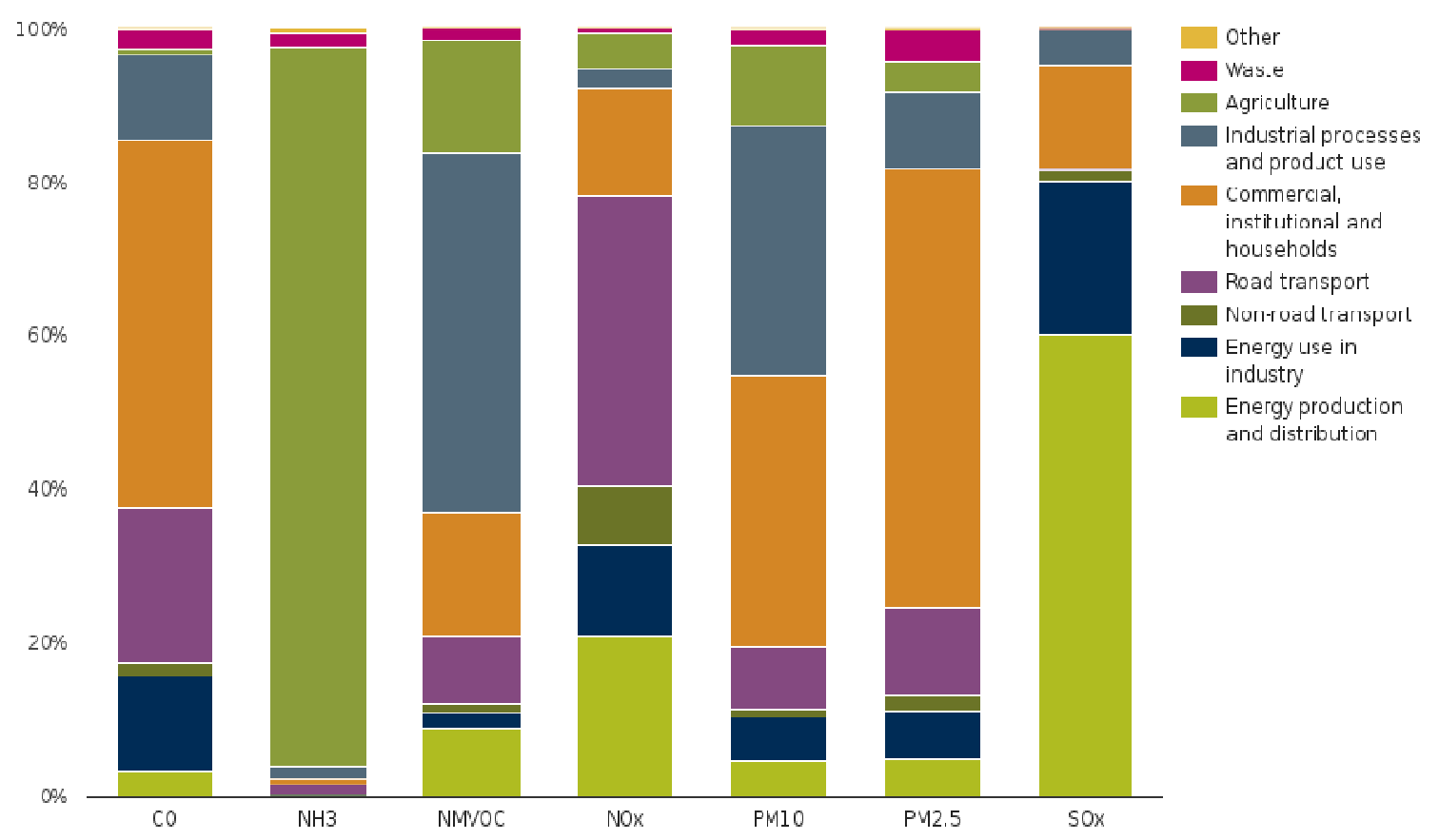

Fig. 1 Emissions of the main air pollutants ${ }^{1}$ by sector group in the EEA-33, 2017 [5].

common ICEs consist of nitrogen oxide (NO) and nitrogen dioxide $\left(\mathrm{NO}_{2}\right)$, both components being toxic gases with negative effects on human health and the environment. Direct $\mathrm{NO}_{2}$ emissions are considered more problematic as they have the most significant health impacts in inner-city areas $[5,6]$, with $\mathrm{NO}_{2}$ reaching about $5-10 \%$ of the total $\mathrm{NO}_{\mathrm{x}}$ emissions of an ICE. Modern diesel engines may consistently exceed this share, depending on the emission reduction system used. Increasingly rigid imposed limits on $\mathrm{NO}_{\mathrm{x}}$ emissions could even bring in the future to a non-returning point for diesel engines technology and its convenience for manufacturers, since they are more problematic with such pollutants [7, 8]. Transport sector is the main anthropological $\mathrm{NO}_{\mathrm{x}}$ source. In fact, these pollutants are emitted by combustion processes that use atmospheric air as the oxidant agent. At high temperatures $\left(1,200-1,300{ }^{\circ} \mathrm{C}\right)$, nitrogen from air is

\footnotetext{
1 NMVOC (non-methane volatile organic compounds) pollution source is comparable in first approximation to NMTHC (non-methane total hydrocarbons), as for mobile applications a share of around $90 \%$ of total hydrocarbons THC are estimated to be constituted by VOC [4].
}

oxidised by oxygen. Resulting nitrogen oxides can be considered at a first look as an index of optimal, efficient, high-temperature combustion, as their production is proportional to thermal energy developed in combustion $[9,10]$, thus the challenge of low- $\mathrm{NO}_{\mathrm{x}}$ burners (LNB) is to reduce $\mathrm{NO}_{\mathrm{x}}$ emissions without decreasing fuel oxidation efficiency.

\subsection{Other Pollutants}

Carbon monoxide (CO) emissions are mostly due to the incomplete carbon combustion of into $\mathrm{CO}_{2}$. Incomplete combustion is a peculiarity in reciprocating internal combustion engines, where combustion is required to be as fast and powerful as possible, even if this is paid in terms of incomplete oxidation reactions. Due to this intrinsic traditional ICE characteristic, road transports sector is the second source of $\mathrm{CO}$ emissions in Europe.

It is defined as particulate matter (PM) the dispersion in atmosphere of either solid particles or droplets. Light, gaseous-burned fuels like natural gas and liquefied petroleum gas, do not produce significant PM fractions. On the other side, a heavier 
fuel (like diesel) would produce a major quantity of PM. In the design and simulations here reported, it will not implement a PM emission map for both CNG and LPG fuel configurations, as this kind of emission can be considered negligible for the used fuels.

Total hydrocarbons (THC) emissions include mostly unburned HCs (UHC) that are fuel portions emerging from the combustor, as well as the products of fuel thermal degradation into lower molecular weight species. Generally, the factors that influence $\mathrm{CO}$ emissions also influence UHC emissions and in much the same manner [11]. The current Euro emissions limits for THC include methane and non-methane hydrocarbon (NMHC) emissions. The main reason for including methane is the fact that it is a strong greenhouse gas.

\subsection{Euro VI normative}

The "Euro VI", when referred to high-duty vehicles (with a mass greater than 2,610 kg), is the current emission normative in Europe, meaning that at present, only Euro VI vehicles can be sold in the EU. Since the 70 s, the increasingly tighter emission limits have led to the introduction of new technologies, consequently there have been some significant reductions in vehicle emissions. One need only think that a Euro 6 diesel car must release $97 \%$ less PM than a 20 -years-older Euro 1 vehicle.

Although results are in evidence, emission reductions from road transport have been lower than originally predicted, partly because transport has grown more than expected, and, for certain pollutants, partly due to a larger than expected growth in diesel vehicles, producing higher $\mathrm{NO}_{\mathrm{x}}$ and $\mathrm{PM}$ emissions than petrol-fuelled vehicle, but, most of all, it is widely accepted that real-world emissions of $\mathrm{NO}_{\mathrm{x}}$, particularly from diesel vehicles, generally exceed the permitted Euro emission standards.

Actually, real-world emissions are a crucial point for current legislation centres and observatories, as many studies [12-16] demonstrate the inability of test procedures that have been performed for many years to correctly determine the real vehicles driving loads and sequences. The reason of the failed correspondence between real and tested emissions is that the NEDC test cycle, previously used for these certifications, does not capture the full range of typical real-world driving operating conditions of the engine map. These inaccuracies have been fixed in the latest Euro 6 and Euro VI directives upgrades that came into force from September 2017. Particularly in the Euro VI standards, old drive-cycles have been replaced by both the World Harmonized Stationary Cycle (WHSC) and the World Harmonized Transient Cycle (WHTC) that were defined alongside with United Nations Economic Commission for Europe (UNECE).

To follow, EURO VI limits (Fig. 2) as specified in its latest review (July 2017), and a comparison between NEDC and WHTC profiles.

From Fig. 3, it can be observed how the newer cycle has a higher level of variability that reflects its real-drive conditions. Therefore, it origins higher emissions and energy request values to the same vehicle body.

To achieve all design goals of an urban transit bus, the procedure will be focused on:

- Ensuring adequate vehicle's performances in following common real-drive cycles;

- Matching the most recent emission standards, namely Euro VI limits specs from 2017, July;

- Minimizing fuel consumption;

- Analysing the transportation cost by the hybrid drivetrain.

\section{Hybrid Configuration}

The chosen design configuration is based on a gas-turbine (GT) power generator as thermal unit of the drivetrain. GT can be ignited by different fuels in two studied cases: compressed natural gas (CNG), and liquefied petroleum gas (LPG). 
Euro VI Emission Limits

\begin{tabular}{l|c|c|c|c|c|c|c|c}
\hline & \multicolumn{7}{|c}{ Limit values } \\
\cline { 2 - 9 } & $\begin{array}{c}\mathrm{CO} \\
(\mathrm{mg} / \mathrm{kWh})\end{array}$ & $\begin{array}{c}\mathrm{THC} \\
(\mathrm{mg} / \mathrm{kWh})\end{array}$ & $\begin{array}{c}\mathrm{NMHC} \\
(\mathrm{mg} / \mathrm{kWh})\end{array}$ & $\begin{array}{c}\mathrm{CH}_{4} \\
(\mathrm{mg} / \mathrm{kWh})\end{array}$ & $\begin{array}{c}\mathrm{NO}_{\mathrm{x}} \\
(\mathrm{mg} / \mathrm{kWh})\end{array}$ & $\begin{array}{c}\mathrm{NH}_{3} \\
(\mathrm{ppm})\end{array}$ & $\begin{array}{c}\mathrm{PM} \text { mass } \\
(\mathrm{mg} / \mathrm{kWh})\end{array}$ & $\begin{array}{c}\text { PM } \\
\text { number } \\
(\# / \mathrm{kWh})\end{array}$ \\
\hline WHSC (CI) & 1500 & 130 & & & 400 & 10 & 10 & $8,0 \times 10^{11}$ \\
\hline WHTC (CI) & 4000 & 160 & & & 460 & 10 & 10 & $6,0 \times 10^{11}$ \\
\hline WHTC (PI) & 4000 & & 160 & 500 & 460 & 10 & 10 & \\
\hline
\end{tabular}

$\mathrm{PI}=$ Positive Ignition.

$\mathrm{CI}=$ Compression Ignition.

Fig. 2 Euro VI limits [16].

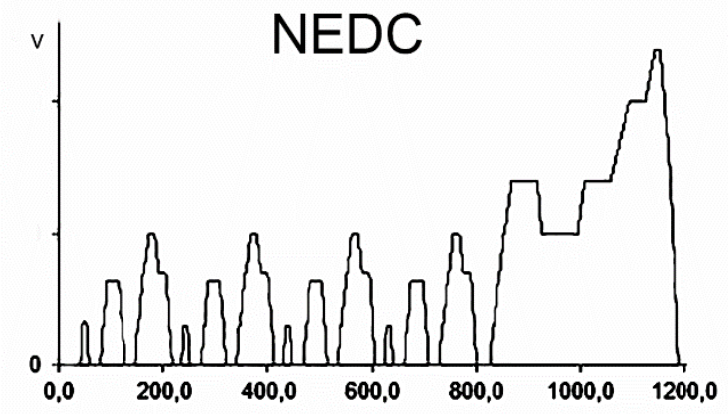

s

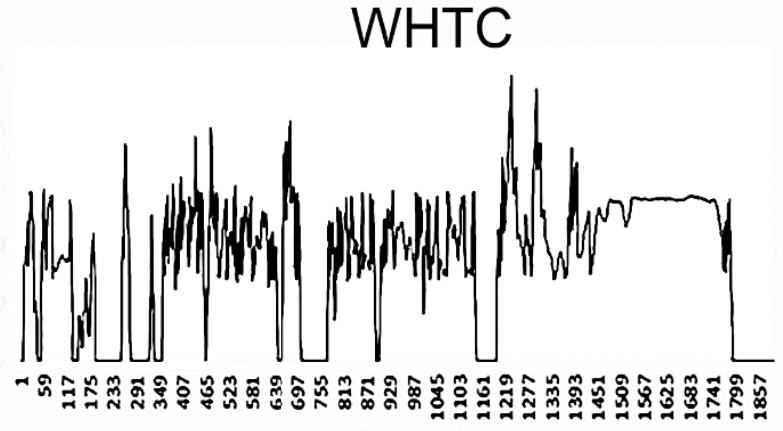

- (v/v_max)

Fig. 3 Profiles of speed-vs.-time sequence in NEDC and WHTC cycles.

\subsection{Overview}

Internal combustion engines monopolised the automotive industry since its origin. However, the emission rate of this kind of powertrains is well over a sustainability-based acceptance level, given the huge increase in vehicles sales all over the global market, as well as vehicles density in the cities.

One of the biggest issues of ICEs is related to the scarce capability in real drive conditions of fully exploiting their efficiency maps. In usual driving condition the efficiency of thermal propulsion systems is quite low, as, despite an ICE is well modulable in power and speed, the required engine operating point is usually well far from the map optimal point (i.e. the minimum specific fuel consumption condition). Therefore, the global average efficiency level is dramatically lowered. Electric propulsion systems are not affected by this problem, as an electric motor provides both average and maximal, largely higher efficiencies. Electric vehicles (EVs) could be a long-term viable research and design path, but this technology is affected by several problems, mainly related to the drivetrain performances in terms of range of autonomy and peak power.

Hybrid electric vehicles (HEVs) stand out as the most promising technology in the short term to satisfy all goals for a road vehicle design:

- Power, for meeting vehicle performance demands;

- Energy density, to carry sufficient onboard energy quantity, to provide an adequate driving autonomy;

- High efficiency, to reduce fuel consumption;

- Low emission levels, to limit vehicle's impact in terms of pollution. 
Hybrids (series configuration) technical strength is to rely on the electric power unit (PU) to absorb the highly variating part of the power request, letting heat engine handle the constant load. It can be also possible to use the thermal PU as a generator for the electric energy storage system. This circumstance is highly competitive in terms of drivetrain efficiency, as it lets the thermal PU work at a constant optimal operating point, that is the minimum specific fuel consumption condition. Thus, the electric storage system operates like a "power damper", and efficiency level is much less deteriorated by load variations [17].

Finally, electric machines are fully reversible, so they can act in both power-release, or regeneration mode by wheel braking, which provides a further efficiency improvement. However, braking kinetic energy recovery system (KERS) must respect the bounds of the maximal power that can be accepted as input for electric storage system. This constraint prevents from a full braking kinetic energy recovery by KERS.

\subsection{GTHV Design Configuration}

The design carried out in the present thesis is based on previous works and studies developed at the Mechanical and Aerospace Engineering Department of Sapienza University, all of them dealing with the same kind of gas turbine hybrid vehicle (GTHV) configuration [18-24]. GTHV is a series hybrid drivetrain where the heat engine is constituted by a small gas turbine (GT), or microturbine (MT), while only the electric PU drives the vehicle (Fig. 4).

From a thermodynamic point of view, GTs run on Joule-Brayton open cycle, which uses constant pressure heat transfer processes with compression and expansion phases in between. Working fluid is air, and it is continuously drawn and compressed in the compressor. Then it moves into the combustion chamber, where it is burned with injected fuel, in a continuative combustion process. At this point, the high-enthalpy flow goes through turbine's blades channels where the fluid is expanded and cooled, while useful power is collected. At the end of the cycle, exhaust gas flow is usually directed to a regenerator to operate the inlet-air preheating.

GTs do not have a very performing response to power modulation and it is more convenient to set it operating at a fixed-speed point of the map. Typically, these engines reach the best efficiency near the full load conditions, at very high speed $(60-90 \mathrm{krpm}$ and higher).

A quick summary of some GTs engines strengths:

- The elevate rotating speed leads to higher power-to-weight ratios, against traditional ICEs, which means a more compact, lighter machines design;

- There are less moving parts, as the only one in a GT is the rotor;

- Combustion is continuous. That means it is well controllable and much more effective in fuel oxidation process. Consequently, $\mathrm{CO}$ and $\mathrm{THC}$ emissions are substantially lesser than those released by a reciprocating ICE;

- Continuous combustion can be even traduced in a very mild dependency by the type of fuel, against a reciprocating ICE. Therefore, a GT can operate with many fuels with almost the same performances.

Main issues from a GT are linked to the more complex design instead, that means higher design, manufacturing and materials costs. Furthermore, the cited hard capability to regulate power is a bad point from GTs, but in a series of hybrid configuration, where to heat engine is asked to operate at a fixed, optimal point, this concern is negligible.

\subsection{Control Logic}

The electronic vehicle management unit (VMU) has the mission to control and operate on all vehicle's parameters, to reach the desired dynamic drivetrain performances. The VMU must have available all the instantaneous values of thermal, mechanical and electrical parameters, in a processable format. These 


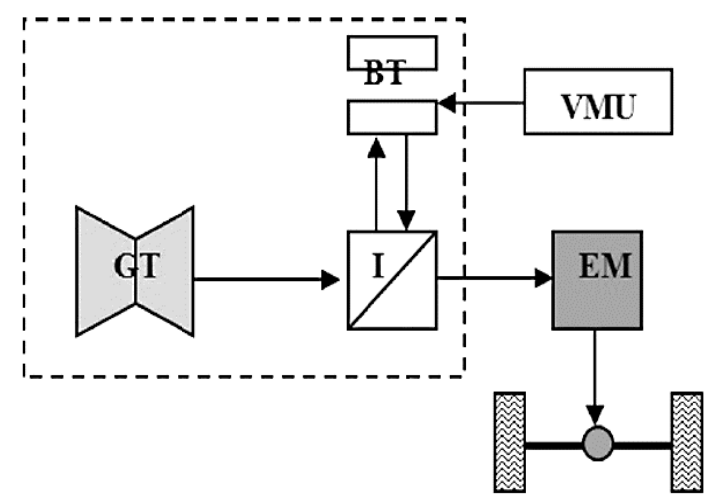

\begin{tabular}{|ll|}
\hline Legend & \\
BT & battery package \\
EM & electric motor \\
GT & gas turbine \\
I & inverter \\
VMU & vehicle management \\
& unit \\
\hline
\end{tabular}

Fig. 4 GTHV series hybrid drivetrain configuration, adapted from Ref. [18].

data include instant required power, closed energy balances for every connection between power components, battery kind, state of charge (SOC) value and its trend, and so on.

In the case of this series GTHV vehicle design, an ON-OFF logic has been implemented for the heat engine, while SOC has been bounded between $80 \%$ and $40 \%$ of nominal storage capacity, to reduce battery cycling stresses. The VMU operates with the following fundamental instructions:

- For reducing fuel consumption and environmental impact, VMU must prefer to drive the vehicle in full-electric mode, namely with the GT unit switched off;

- GT is ignited whenever SOC falls under its minimum admissible value, that is 0.4 ;

- Once GT is switched on, it is set to run at fixed optimal point, equal to its rated power. In this way, the machine works on its optimal efficiency point, without being affected by any load variation. Thermal PU is sized on the mean power load (average of driving + recharging demand), with a consistent downsizing against a traditional (or parallel hybrid) drivetrain;

- The instantaneous power surplus, with respect to the driving load, is stored in the energy storage system (ESS);

- Once SOC has risen up to 0.8 , GT unit is turned-off again, the vehicle returns in full-electric mode, while SOC restarts to fall;
- At the end of each mission, the GT must recharge the ESS, to start the successive mission with the maximum value of electric autonomy.

The limitation of the battery operational range to the admissible SOC range (40-80\%), seems to be costly as it leads to force an ESS oversizing, which means a further enlargement of battery capacity and expenditure. However, this constraint is motivated by the strong necessity to maximize the battery life-cycles number, that is an inverse function of their width. Another important reason to not exceed $80 \%$ of $\mathrm{SOC}$ is that for higher values, kinetic recovery is no longer possible, as battery maximal instantaneous receivable power tends to be very scarce for high SOC values.

\section{Design Process}

The hybrid transit bus design started with the definition of some base parameters like weight, dynamic resistances loads, power, energy storable, emission boundaries. Then, each component has been individually analysed, and its key-parameters have been defined as well. Design and simulation processes have been developed in mutual conjunction, with a continuous iterative interaction between simulations results and key-parameters adjustment. The aim is to ensure that the components design is adequate to the mission, without oversizing, in order to size a closely fitting hybrid drivetrain over the body of a common public transport bus. 
Table 1 Vehicle characteristics.

\begin{tabular}{llll}
\hline Iveco-Irisbus 491 Cityclass diesel & & CNG version differences \\
\hline$L$ & $11.995 \mathrm{~m}$ & length & - \\
$H$ & $2.96 \mathrm{~m}$ & height & $3.23 \mathrm{~m}$ \\
$W$ & $2.5 \mathrm{~m}$ & width & - \\
$A_{f}$ & $7.24^{(*)} \mathrm{m}^{2}$ & frontal area & $7.9^{(*)} \mathrm{m}^{2}$ \\
$C_{d}$ & $0.7^{(* *)}$ & drag coefficient & - \\
tyres & $275 / 70-\mathrm{R} 22.5$ & & - \\
$m$ & $11,650 \mathrm{~kg}$ & empty mass & $12,600 \mathrm{~kg}$ \\
$m_{M A X}$ & $18,790 \mathrm{~kg}$ & full-load mass (max tolerated) & $18,992 \mathrm{~kg}$ \\
$\operatorname{tank}$ & $320 \mathrm{~L}$ & & $1,296 \mathrm{~L}(8 \times 162)$ \\
$c$ & $51 \mathrm{~L} / 100 \mathrm{~km}$ & fuel consumption & $56 \mathrm{~L} / 100 \mathrm{~km}$ \\
$f_{r}$ & $0.014^{(* *)}$ & rolling resistance coefficient & - \\
\hline
\end{tabular}

${ }^{(*)}$ Approximated; ${ }^{(* *)}$ estimated from tables from Ref. [26].

\subsection{Base Parameters Definition}

Referring to a typical standard (not articulated), single-decker chassis of a city bus, it can be possible to define weights and dimensions of the vehicle, as well as its principal dynamic parameters. There has been used the body of one of the most diffused public bus in Rome, the Iveco-Irisbus 491 Cityclass [25].

After having set the vehicle weight and dimensions, it remains to fix the speed targets, which have a direct influence on required power and energy values.

Euro VI last update imposes two different drive cycles over which all the emission limits are separately defined. These are World Harmonised Steady Cycle (WHSC) and World Harmonised Transient Cycle (WHTC), respectively referring to steady or transient conditions. Both World Harmonised cycles are defined as a composition of different engine working points - modes_but, while the WHSC is not clearly

$$
\begin{aligned}
& P_{m c}=\frac{R_{\text {tot }}}{\eta_{m c}} \cdot v_{\text {max }} \quad[\mathrm{Kw}] \\
& R_{\text {tot }}=R_{\text {in }}+R_{\text {roll }}+R_{\text {air }}+R_{\text {grad }} \quad[\mathrm{N}] \\
& R_{\text {in }}=c_{i} m a ; \quad R_{\text {roll }}=f_{r} m g \cos \alpha ; \\
& R_{\text {air }}=\frac{1}{2} \rho_{\text {air }} C_{d} A_{f} v^{2} ; \quad R_{\text {grad }}=m g \operatorname{sen} \alpha ;
\end{aligned}
$$

where,

$\mathrm{R}_{\text {in }}=$ inertial resistance

$\mathrm{R}_{\text {roll }}=$ rolling resistance

$\mathrm{R}_{\mathrm{air}}=$ air resistance

$\mathrm{R}_{\text {grad }}=$ road gradient

resistance

$\alpha=$ ground angle

\begin{abstract}
$\mathrm{c}_{\mathrm{i}}=1$; inertial and rotating masses coefficient (its values exceeding unit are mostly due to clutch rotating masses). In GTHV transmission this effect is negligible and $c_{i}$ is equal to 1 $\rho_{\text {air }}=1.22 \mathrm{~kg} / \mathrm{m}^{3}$; air density.
\end{abstract}

Using a calculator for coupling this set of equations with the speed sequence, it is possible to extract for every time-step $t$, the required motoring power. However, it is quite complicated to interpret the 
outcoming data. In fact, the algebraic calculation of required power for the WHTC, outcomes almost $350-400 \mathrm{~kW}$, clearly exceeding values, for a kind of vehicle like the considered one.

The fact is that the measure is extremely distorted by a main factor, namely that time-speed sequence imposes a high rate of acceleration to the vehicle $\left(a_{\max }\right.$ $\left.=2.5 \mathrm{~m} / \mathrm{s}^{2}\right)$, but such a heavy-duty bus does not actually provide these acceleration values. Moreover, both normative and simulator admit a band of incongruence in speed profile matched by the investigated vehicle. In this work, the maximum admissible speed deviation from the drive-cycle path is set to $\pm 3.2 \mathrm{~km} / \mathrm{h}$, equal to $2 \mathrm{mph}$ (default value for Advisor iterations), and acceleration is limited to 1 $\mathrm{m} / \mathrm{s}^{2}$. Such an adjustment leads to a more comfortable design, that starts from the observation of similar heavy-duty vehicles [25, 28-30], all equipped with about $200 \mathrm{~kW}$ PUs. Thus, a first value for required motoring power is set to $200 \mathrm{~kW}$. Following simulations are expected to confirm that it is an adequate value for this kind of application, for reaching sufficient drive-cycle performances within the admissible speed matching bounds.

\subsection{Required Storable Energy}

The capacity of the energy storage system (ESS) is mainly influenced by vehicle's autonomy range in full-electric mode. The higher is the desired autonomy, in terms of time and distance, the higher must be the battery capacity, and, most of all, its cost. On one hand, the installation expense for the storage system increases quite linearly with its capacity, as the unit cost $(€ / \mathrm{kWh})$ of a battery is primarily determined by its technology level, and just a little bit by size (Fig. 5). On the other hand, there is to account for batteries lifetime, which is basically determined by the product of its guaranteed charge-discharge cycles number, times their frequency. Obviously a larger ESS has a longer lifetime if compared with a smaller one, as the former needs a minor charge-discharge frequency on

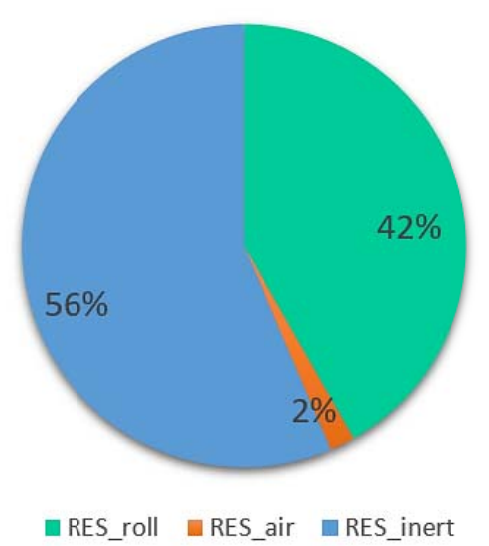

Fig. 5 Estimated energy expense shares by driving resistance in a WHTC cycle with max speed of $60 \mathrm{~km} / \mathrm{h}$, for an urban transit bus.

equal drivetrain missions. Therefore, the larger is ESS capacity, the greater is its installation cost, but the lesser is its unitary per-mission cost derived from its periodic substitution. Such a balance must be optimized, making the more convenient choice for the installed ESS capacity value.

Moreover, the design of an ESS for a series HEV, like the GTHV, must also satisfy the driving power requirement constraint, as a battery must be able to release enough power to absorb the peak driving request.

In this specific case, energy requirements calculations can be faced with a common calculator, as, while instant power request is very sensible to the imposed acceleration surplus, due to the inertial resistance term, energy instead is not so much influenced by that. Then, it is possible to use the reported vehicle-dynamics formulas to estimate a first-trial value for the required amount of storable energy that such a kind of heavy-duty HEV would need in real-drive conditions. The calculus over the drive-cycle speed sequence gives out the average power request equal to about $50 \mathrm{~kW}$. This means that a $50 \mathrm{kWh}$ capacity battery, would be fully discharged in 1 hour (ideal conditions), in full electric mode. However, GTHV SOC bounds do not admit a complete $100-0 \%$ discharge, in fact SOC range is set to $80-40 \%$. Thus, if the bus must run in full-electric 
mode for at least an entire WHTC cycle (lasting 1,800 $\mathrm{s})$, it shall be equipped with a battery capacity given by the formula:

$$
E S S_{\text {cap }} \geq \bar{P} \cdot \frac{t_{d, \min }}{U_{E S S}} \quad[\mathrm{kWh}]
$$

where $\bar{P}=50$, is the average required power $[\mathrm{kW}]$; $t_{d, \min }=0.5$, represents the minimum full-electric desired autonomy $[\mathrm{h}] ; U_{E S S}=0.8-0.4=0.4$, is the utilisation factor of the whole ESS capacity, namely the effective (exploited)-to-nominal capacity ratio. Thus, as a first-trial value for drivetrain sizing, it results:

$$
E S S_{\text {cap }} \geq 62.5 \mathrm{kWh}
$$

The resulting first values of design key-parameters have been set and reported in the following table (Table 2).

\subsection{Electric Motor}

Electric motors constitute an optimal design choice for a vehicle drivetrain, as their torque and speed characteristics well satisfy the vehicle dynamics basic requirements, especially in applications where there is no need of extremely high-speed rates, like in the case in exam. The recent HEVs employ AC and brushless motors, which include induction motors (IM), permanent magnet motors (PM), and switched reluctance motors (SRM). IM and PM are commonly retained to be the better choice for automotive applications [31-33].

The designed vehicle utilizes an AC-PM motor, as this kind of machine provides the maximum power-to-weight ratio among EMs technologic supply. Of course, the EM must satisfy the mission power request set by the peak value of $200 \mathrm{~kW}$. To satisfy that, it has been chosen a model from AVID Technology Ltd, a UK-based company which produces powertrain components for hybrid and electric vehicles (Fig. 6 and Table 3). To follow, there are reported the chosen model characteristics, from Ref. [34]:

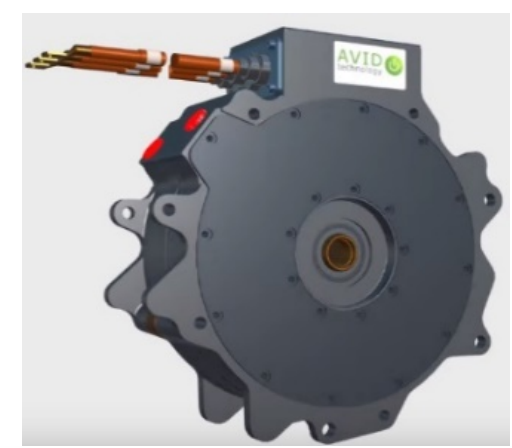

Fig. 6 CAD image of the AVID-EVO EM, providing high torque and power densities [34].

Table 2 GT device characteristics.

\begin{tabular}{lll}
\hline GTHV, 19 tons urban transit bus, WHTC & \\
\hline$v_{\max }$ & $60 \mathrm{~km} / \mathrm{h}$ & max speed \\
$\sigma$ & $\pm 3.2 \mathrm{~km} / \mathrm{h}$ & admissible deviation from imposed drive-cycle \\
$P_{\text {req }}$ & $200 \mathrm{~kW}$ & required power \\
ESS $_{\text {cap }}$ & $\geq 62.5 \mathrm{kWh}$ & minimum battery pack capacity \\
\hline
\end{tabular}

Table 3 Electric motors specifications.

\begin{tabular}{lll}
\hline Electric motor AVID EVO, AF-240 & & \\
\hline Max speed & $5,000 \mathrm{rpm}$ & up to $20 \mathrm{~s}$ \\
Peak output power & $400 \mathrm{~kW}$ & \\
Nominal output power & $188 \mathrm{~kW}$ & up to $20 \mathrm{~s}$ \\
Peak torque & $1,200 \mathrm{Nm}$ & \\
Nominal torque & $520 \mathrm{Nm}$ & $\mathrm{L} \times \mathrm{D}$ \\
Peak efficiency & $95.5 \%$ & \\
Dimensions & $224 \times 380 \mathrm{~mm}$ & \\
Weight & $82 \mathrm{~kg}$ & \\
Minimum voltage & $320 \mathrm{~V}$ &
\end{tabular}


Table 4 Battery package nameplate.

\begin{tabular}{lll}
\hline Energy storage system, KAITEK K-Lithium Cells $24 \mathrm{~V}-100 \mathrm{Ah} \mathrm{Slim}\left(\mathrm{LiFePO}_{4}\right)$ & \\
\hline Cell nominal voltage & $24 \mathrm{~V}$ & \\
Cell nominal capacity & $100 \mathrm{Ah}$ & \\
Cells number & 27 & \\
Cells disposition & Series & \\
Total nominal voltage & $648 \mathrm{~V}$ & $\mathrm{~L} \times \mathrm{D} \times \mathrm{H}$ \\
Total energy & $64.8 \mathrm{kWh}$ & \\
Dimensions & $27 \times(620 \times 144 \times 327) \mathrm{mm}$ & \\
Weight & $27 \times 40 \mathrm{~kg}=1,080 \mathrm{~kg}$ & up to $10 \mathrm{~s}$ \\
Rate of discharge & $1.5 \mathrm{C}$ & \\
Peak rate of discharge & $3 \mathrm{C}$ & limited time \\
Rate of charge & $0.5 \mathrm{C}$ & \\
Peak rate of charge & $1 \mathrm{C}$ & \\
Power output at $1.5 \mathrm{C}$ discharge & $97.2 \mathrm{~kW}$ & \\
Power output at $3 \mathrm{C}$ discharge & $194.4 \mathrm{~kW}$ & \\
Operating temperature & -20 to $60^{\circ} \mathrm{C}$ & \\
Life & $3,000 \mathrm{cycles}$ & \\
Cost & $30,000 €$ &
\end{tabular}

\subsection{Battery Pack}

Energy storage system is the most crucial element in a series of HEV design, given its relevance in terms of global costs, weights, technology level. It also plays a major role in determining technical attributes such as performances and driving range.

Batteries technology is critical in global performances if compared with others drivetrain's components state-of-art. However, this disadvantage is partially balanced by the higher efficiency from the electric components of the drivetrain. The user must install several cells (series or parallel disposed) on the vehicle. The kind of battery pack which results as dominant and better performing with respect to the others is the Li-ion based one, which works with lithium ions migration flux, between a cathode made by a lithium compound and the anode, typically carbon. These ESSs guarantee the best mix of key parameters for EVs applications design nowadays, such as higher energy densities to increase full electric-driving range, safety, lifetime and costs. One of most diffused cathode materials is the olivine $\mathrm{LiFePO}_{4}$, as it shows some important advantages: the highest theoretical capacity of all known cathode materials $(170 \mathrm{mAh} / \mathrm{g})$, the highest thermal stability, which guarantees safety of use and stable capacity after a high number of cycles [35]. For this specific application, the ESS is demanded to provide a peak power of $200 \mathrm{~kW}$ and a rated capacity of $60-70 \mathrm{kWh}$ at least. For better facing the design of a suitable battery pack, it has undertaken a precious information exchange with the Italian ESS producer Kaitek srl (RE, IT). The supplied data claim that such a $\mathrm{Li}$-ion cell with $\mathrm{LiFePO}_{4}$, can observe a $1.5 \mathrm{C}$ continuous rate of discharge, which rises up to $3 \mathrm{C}$ for brief peaks $(10 \mathrm{~s})$. About charge rate instead, its rated value is set to 0.5 $\mathrm{C}$ continuously and $1 \mathrm{C}$ for peaks. Moreover, it has specified the indicative cost of these devices, namely about $500 € / \mathrm{kWh}$, which also includes all cables, BMS, boxes, charging devices.

Thus, the proposed preliminary design sets an ESS constituted by a series-connection of 27 prismatic cells by Kaitek, each one characterized by $24 \mathrm{~V}$ and $100 \mathrm{Ah}$. In this way, the ESS nominal voltage output is maximized to $648 \mathrm{~V}$, to fulfil the constraint about motor's minimum voltage input, at the same time minimizing currents and conduction losses. The following table (Table 4) reports the ESS key-parameters. 


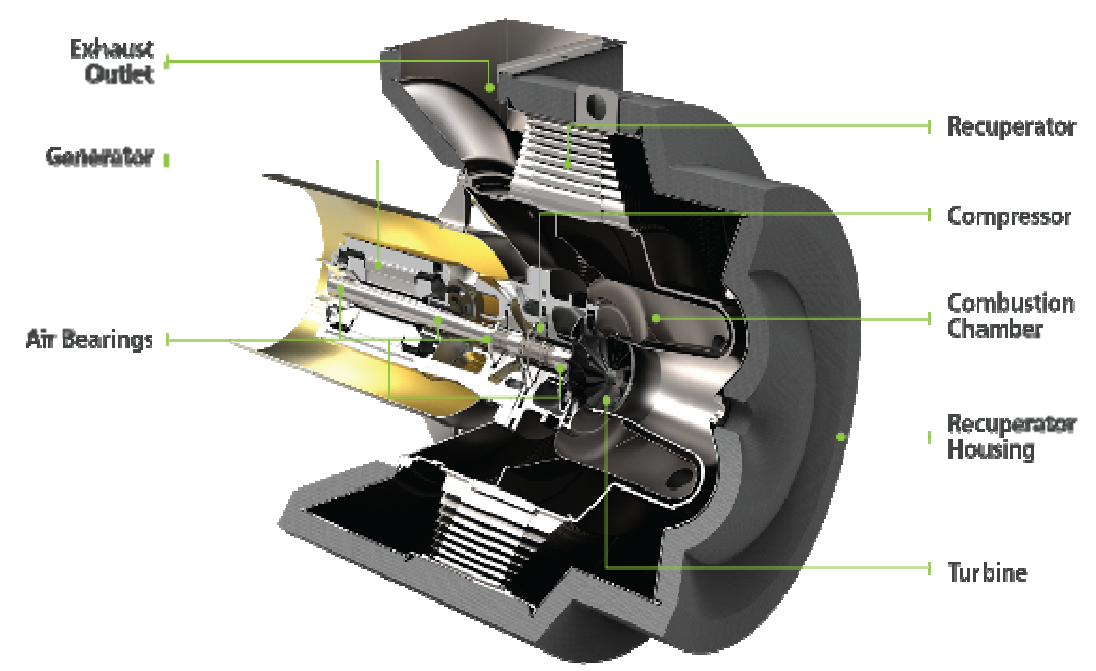

Fig. 7 Typical MT design and view, from Capstone website [40].

\begin{tabular}{lcccc}
\hline Emissions Characteristics & System 1 & System 2 & System 3 & System 4 \\
\hline Nominal capacity $(\mathrm{kW})$ & 30 & 70 & 80 & 100 \\
Electrical efficiency $(\%), \mathrm{HHV}$ & 23 & 25 & 24 & 26 \\
$\mathrm{NO}_{\mathrm{x}}$ (ppmv at $15 \% \mathrm{O}_{2}$ ) & 9 & 9 & 25 & 15 \\
$\mathrm{NO}_{\mathrm{x}}$, lb/MWh & 0.51 & 0.45 & 1.25 & 0.72 \\
$\mathrm{CO}$ (ppmv) & 40 & 9 & 50 & 15 \\
$\mathrm{CO}(\mathrm{lb} / \mathrm{MWh})$ & 1.38 & 0.27 & 1.51 & 0.45 \\
$\mathrm{THC}(\mathrm{ppmv})$ & $<9$ & $<9$ & $<9$ & $<9$ \\
$\mathrm{THC}(\mathrm{lb} / \mathrm{MWh})$ & $<0.18$ & $<0.16$ & $<0.16$ & $<0.15$ \\
$\mathrm{CO}_{2}$ (lb/MWh) & 1765 & 1585 & 1650 & 1535 \\
\hline
\end{tabular}

Fig. 8 Emissions factors, typical guaranteed levels by manufacturers [36].

$1 \mathrm{lb}=453.6 \mathrm{~g}$; thus $0.51 \mathrm{lb} / \mathrm{MWh}=0.51 \times 0.4536 \mathrm{~g} / \mathrm{kWh}$ and so on.

\subsection{Microturbine}

The thermal power source of the designed drivetrain is a microturbine (MT), namely a classic gas turbine whose power is less than $300-400 \mathrm{~kW}$. The crucial parameters of a MT for such an HEV drivetrain design, are the power output and the emission factors.

After an iterative cycle of simulations and design adjustments, rated GT power has been set to $100 \mathrm{~kW}$, to guarantee to the vehicle a reasonable ratio (about 1:1) between discharge and charge operations time, during a long mission composed by many WHTC drive-cycle repetitions. Clearly, a smaller unit $(65 \mathrm{~kW}$, Fig. 7) would mean a lighter and more economic machine, but at the same time, batteries' recharging time would increase, corresponding to excessive GT ignition time, that is, worst fuel economy.
Emission factors are coefficients that give a measure of machine pollution agents released quantities, in terms of pollutant mass-to-energy output ratio $(\mathrm{g} / \mathrm{kWh})$. Emission factors vary by turbine model, type of fuel, pollutant. However, actually it is not easy to find and select from literature an unquestionably reliable set of values for such coefficients, as usually every author mentions a different emission factor for a specific turbine model and/or size (Fig. 8). Even if one tries to refer to a producer's datasheet there is no certainty of surely reaching a unique value for a single model and fuel. In this work, it has been chosen to follow a conservative way to select and set the emission factors values for the simulations. This means that, given two or more authors/data sources, it has been chosen the higher emission factor value, taking into account several refs [36-39]. 


\begin{tabular}{|c|c|c|c|}
\hline Fuel & $\begin{array}{c}\text { Stoichiometric } \\
\text { Flame Temp. }\end{array}$ & $\begin{array}{c}\mathrm{NO}_{\mathrm{x}} \text { (ppmvd/ppmvw-Methane) } \\
1765^{\circ} \mathrm{F} / 963^{\circ} \mathrm{C}-2020^{\circ} \mathrm{F} / 1104^{\circ} \mathrm{C} \\
\text { Firing Time }\end{array}$ & $\begin{array}{c}\mathrm{NO}_{\mathrm{x}} \text { (ppmvd/ppmvw-Methane) @ } \\
15 \% \mathrm{O}_{2}, 1765^{\circ} \mathrm{F} / 963^{\circ} \mathrm{C}-2020^{\circ} \mathrm{F} / 1104^{\circ} \mathrm{C} \\
\text { Firing Time }\end{array}$ \\
\hline Methane & 1.000 & $1.000 / 1.000$ & $1.000 / 1.000$ \\
\hline Propane & 1.300 & $1.555 / 1.606$ & $1.569 / 1.632$ \\
\hline Butane & 1.280 & $1.608 / 1.661$ & $1.621 / 1.686$ \\
\hline
\end{tabular}

Fig. 9 Relative thermal $\mathrm{NO}_{\mathrm{x}}$ emissions [41].

Table 5 UMGT specifications.

\begin{tabular}{lll}
\hline Microturbine & & \\
\hline & $\mathrm{CNG}$ & LPG variations \\
\hline Max power output & $100 \mathrm{~kW}$ & \\
Electrical efficiency & $0.32 \mathrm{kWh} / \mathrm{kWh}_{\text {fuel }}$ & $7.59 \mathrm{~g} / \mathrm{s}$ \\
Fuel consumption & $(*)$ & $0.354 \mathrm{~g} / \mathrm{kWh}_{\mathrm{el}}$ \\
$\mathrm{NO}_{\mathrm{x}}$ emissions & $0.17 \mathrm{~g} / \mathrm{s}$ & \\
$\mathrm{CO}$ emissions & $0.373 \mathrm{~g} / \mathrm{kWh}_{\mathrm{el}}$ & \\
THC emissions & $<0.077 \mathrm{~g} / \mathrm{kWh}_{\mathrm{el}}$ & \\
PM emissions & Negligible & \\
\hline
\end{tabular}

(*) See also Table 6 , and note 2 .

Table 6 GT device specific fuel consumption (sfc).

\begin{tabular}{lll}
\hline & CNG & LPG \\
\hline Fuel consumption & $7.17 \mathrm{~g} / \mathrm{s}$ & $7.59 \mathrm{~g} / \mathrm{s}$ \\
HHV & $52.59 \mathrm{MJ} / \mathrm{kg}$ & $49.68 \mathrm{MJ} / \mathrm{kg}$ \\
\hline
\end{tabular}

There have been considered Systems 1 and 2 from Fig. 8, as they show the same PPMV (parts per million volume) level of C65 and C200 (the latter has also a 4 PPMV low-emitting version) MTs from Capstone [37, 38, 40], respectively rated of 65 and $200 \mathrm{~kW}$. The datasheets from these two models declare respectively 0.08 and $0.18 \mathrm{~g} / \mathrm{kWh}$ of $\mathrm{NO}_{\mathrm{x}}$ releases, that are the most delicate pollutants for an MT PU subject to emission testing. Therefore, to achieve a further level fidelity and reliability in results, it has been used for $\mathrm{NO}_{\mathrm{x}}$ (and other pollutants) emission factor, the average value between Systems 1 and 2 from Fig. 8, which are both higher than datasheets claimed ones.

This was about a CNG fuelled machine, while for the version using LPG fuel must be considered a further increase in $\mathrm{NO}_{\mathrm{x}}$ emission factor. A report by GE [41] states that $\mathrm{NO}_{\mathrm{x}}$ emissions from propane and butane fuels (LPG components) are a constant fraction above those of CNG, which Fig. 9 reports. Therefore, for achieving a reliable value for $\mathrm{NO}_{\mathrm{x}}$ emission factor by an LPG fuelled MT, the value from the CNG turbomachine must be multiplied by a factor in the range 1.6-1.66.

The resulting design key-parameters for the GT (MT) unit are listed in Table 5.

\section{Simulations}

The goal of the simulations is to achieve a reliable estimation of fuel consumption and emission releases by the GTHV bus over a mission composed by several repetitions of WHTC drive cycles, for comparing the output data with the Euro VI limits.

Advisor, acronym of Advanced Vehicle Simulator, is a free [42] Matlab-based software which is provided by US' NREL (National Renewable Energy Laboratory). It works in the Matlab-Simulink environment, with an own graphical user interface. It is used as a system analysis tool for vehicle modelling and simulation, with a special attention to hybrid 
drivetrain configurations. It has been used by different OEMs such as Chrysler, Ford, GM etc. [43]. Its main objective is to predict, through many output data, the performances of still-not-built vehicles.

\subsection{Vehicle Setup}

Two preliminary steps must be executed before launching a simulation on Advisor:

- Defining the vehicle, through the set of input data from its components;

- Assigning the mission, that is the drive-cycle.

The first screen by Advisor allows the user to compose the desired drivetrain through many different predefined or custom schemes (parallel hybrids, series, fuel cells, traditional ICE, and so on). For each scheme, every component of the vehicle is defined by a script on Matlab editor which contained all its specifications. At this step, all components scripts must be opportunely modified and renamed, to be representative of the chosen elements.

During the process of scripts creation/modification, the point was focused on PUs and battery pack, for matching the real conditions and specifications of these components.

The fuel converter, that is the GT unit, is modelled using data from one of the major suppliers, Capstone Microturbine Corporation. Electrical efficiency is set to 0.32 . In the vehicle setup from Fig. 10, GT and generator items are controllable as distinct components, while electrical efficiency of GT group is the aggregate data for the two components. Thus, it has set the electric generator efficiency to 1 , while all losses are accounted in the GT (fuel converter) component script. Fuel consumption is given in terms of power input from C200 datasheet [38], and it is equal to $2,400 \mathrm{MJ} / \mathrm{h}$ (MJ of Higher Heating Value, HHV). This means that fuel consumption values (in $\mathrm{g} / \mathrm{s}$ ) are different for fuels with different HHVs. Not being available the entire map-range data, fuel consumptions for GTs (CNG and LPG fuelled) are set equal to values from datasheets (scaled in power) ${ }^{2}$, right in the operating point. This is an acceptable choice in a constant, full-load control logic:

- The electric motor has been reduced in overtorque factor, to provide the maximum power value of $110 \%$ its nominal power. This means a maximum motoring peak power of $206.8 \mathrm{~kW}$. Peak power limit is necessary to match the ESS instantaneous discharge limit, avoiding current overloads.

The ESS uses data from Table 4. Notice that module's internal resistance values and its variations with SOC were not available, thus these variables have been referred to opportunely modified data from a default file in Advisor directories (ESS_LI7_temp.m), that is representative of a Li-ion module.

Other remarkable vehicle's setup operations:

- Powertrain control has been set to let the MT provide to the generator, in the described On-Off logic, a constant power value, equal to its maximum (full load);

- Gear ratio has been reduced (-12.5\%), after a brief by-trial optimization;

- Vehicle body data, as well as wheels' ones, have been set in the respective files;

- The total mass of the vehicle is defined to match the maximum tolerated value by axles, as reported in Table 1. Therefore, the total mass is set equal to 19 tons, including a little further oversizing. It represents the full-load operating conditions of an urban transit bus.

\subsection{Driving Cycle}

In the simulation setup screen, there are all the

\footnotetext{
${ }^{2}$ Datasheets of C65 and C200 MTs from Capstone [37, 38] report respectively $919 \mathrm{MJ} / \mathrm{h}$ and $2,400 \mathrm{MJ} / \mathrm{h}$ as values of fuel consumption. These correspond to different values in $\mathrm{g} /(\mathrm{s} \cdot \mathrm{kW})$ between the two machines, that are respectively (CNG version) equal to 0.0747 and 0.0634 , that is a $15 \%$ difference (i.e. the larger is a machine, the lesser is its fuel consumption, per unit of output power). To account for this circumstance, it has calculated the weighted (on power output) average value of such a data for a $100 \mathrm{~kW}$ turbomachine, that is $0.0717 \mathrm{~g} /(\mathrm{s} \cdot \mathrm{kW})$ for the CNG fuelled MT. Derived values in $(\mathrm{g} / \mathrm{s})$ are reported in Table 6.
} 


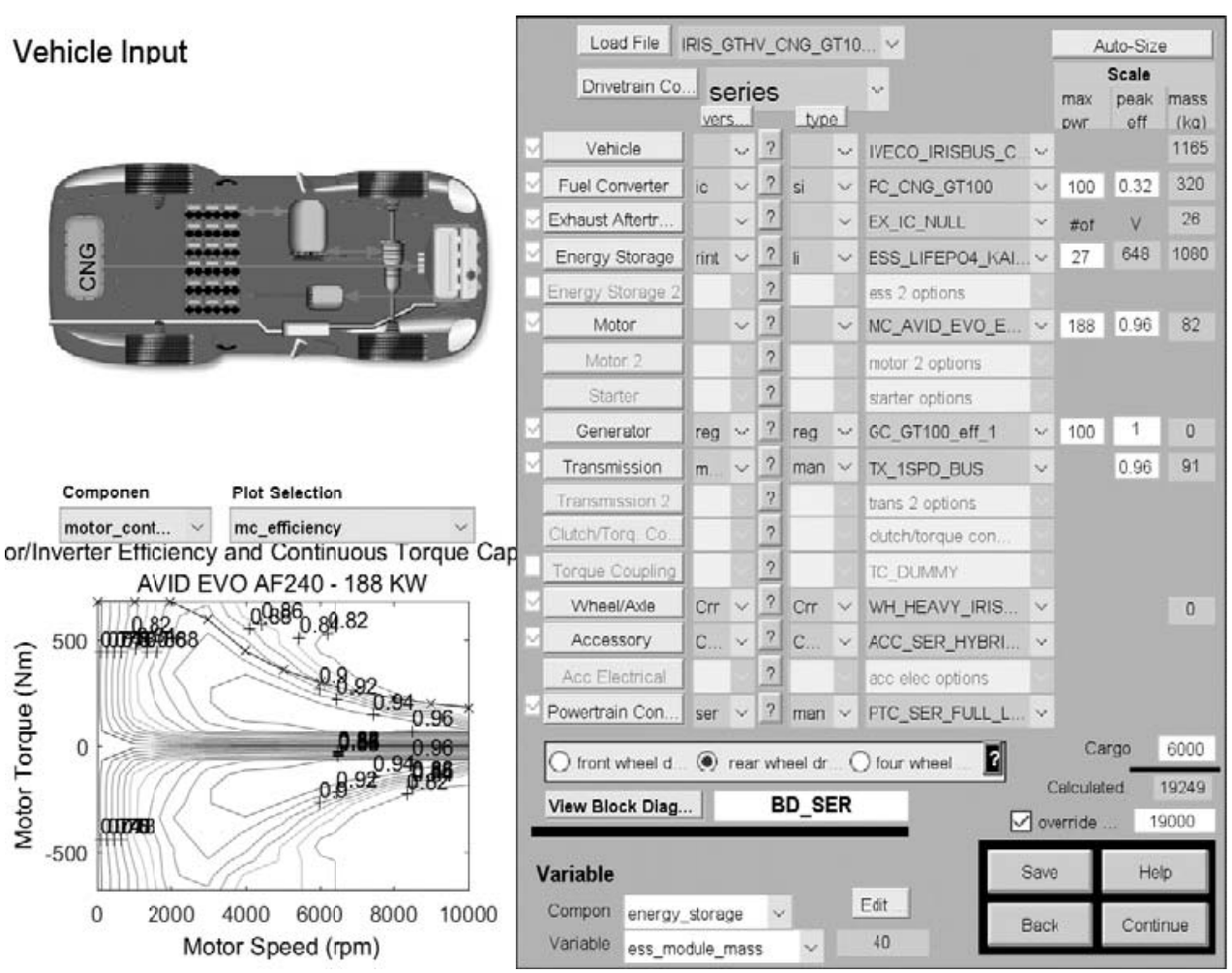

Fig. 10 Advisor, vehicle setup screen.
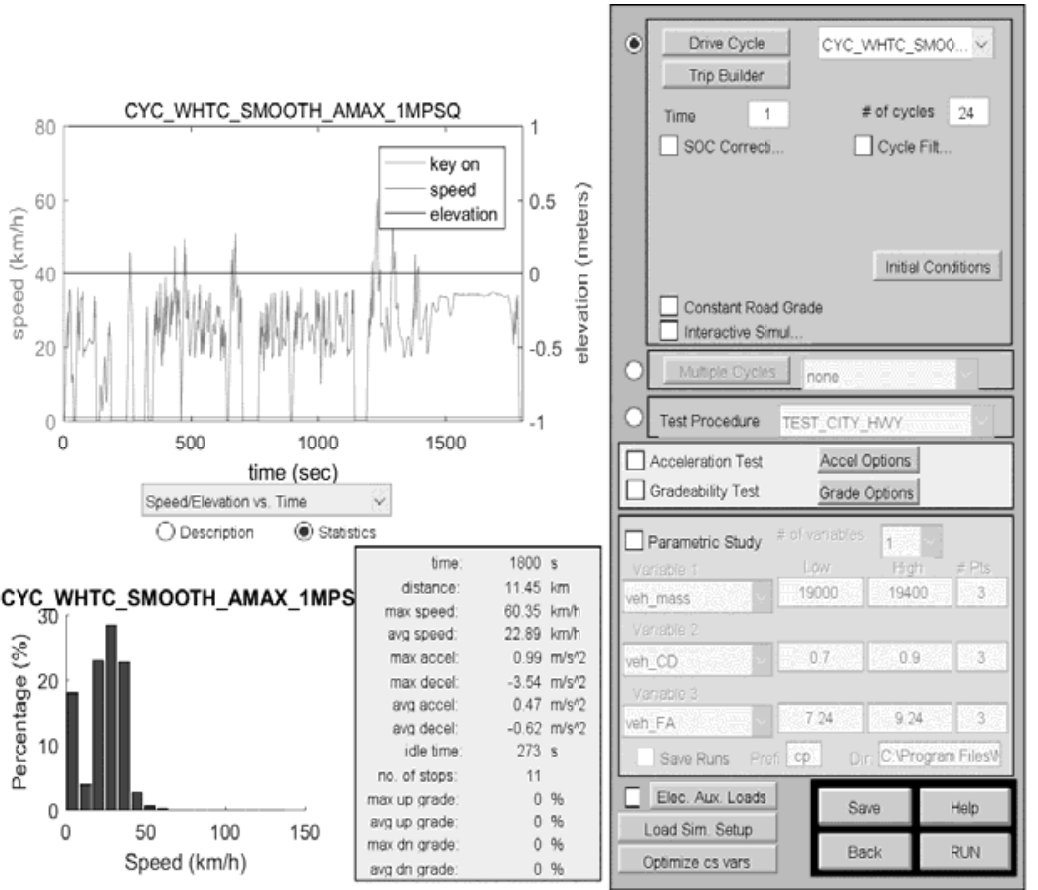

Fig. 11 Advisor, simulation setup screen.

characteristics of the drive-cycle, which has been created through Matlab editor, as well as its speed-vs.-time profile and the number of cycle repetition to run.
The WHTC test has a duration of 1,800 seconds. The higher variance in its profile reveals its greater impact in terms of energy requirements to the vehicle, if compared with an old NEDC. It has been implemented 
a "smooth" version of WHTC cycle, where accelerations are limited to a maximum value of $1 \mathrm{~m} / \mathrm{s}^{2}$. Such an adjustment is largely acceptable for this kind of application. For simulating a real-drive scenario for an urban transportation vehicle it has been set the number of repetitions equal to 24 , to simulate drivetrain's performances over a realistic 12-hours continuative operating interval. It is closely representative of a daily $8 \mathrm{am}-8 \mathrm{pm}$ turn. Finally, initial conditions have been set, by imposing 0.8 as starting SOC value.

\subsection{CNG Results}

The last screen from Advisor reports the simulation results, through tables and selectable graphs that show the behaviour of every key-parameter, by any component, along the entire drive-cycle.

It is remarkable the good level of coherence between the imposed and the achieved speed, as well as the correct shape SOC variations [44-46], limited to the specified range 0.4-0.8, and the GT emissions, whose result is stable, in correspondence with turbine's ignition. However, notice that the frequency of charge-discharge cycles of ESS is quite high, as it requires to be recharged 10 times per day (12 hours driving turn). Final SOC value is maximum and the vehicle is ready to restart another mission after the refuelling.

Table 7 reports all the key-values resulting from the simulation of the $\mathrm{CNG}$ vehicle.

The table highlights the substantial saving in emissions, with respect to the tight normative from EU. This means that such a hybrid configuration could become an innovative alternative technology to face the recent (and future) increase in norms' strictness. It remains to consider the economic impact of such hybrid drivetrain in terms of fixed production costs, as well as the transportation cost it would require, in comparison with analogues traditional ICE vehicles.

\subsection{LPG Results}

The LPG vehicle simulation differs from the CNG one by fuel consumption and emissions, while the other performances are substantially equivalent. LPG produces more $\mathrm{NO}_{\mathrm{x}}$ than $\mathrm{CNG}$, its energy density is higher $\left(\mathrm{J} / \mathrm{m}^{3}\right)$, but its specific energy is lower $(\mathrm{J} / \mathrm{kg})$. Therefore, it is expected a higher $\mathrm{NO}_{\mathrm{x}}$ emission level, and a lower consumption in volume of fuel. Results confirm the expectations, as $\mathrm{NO}_{\mathrm{x}}$ emissions increased,
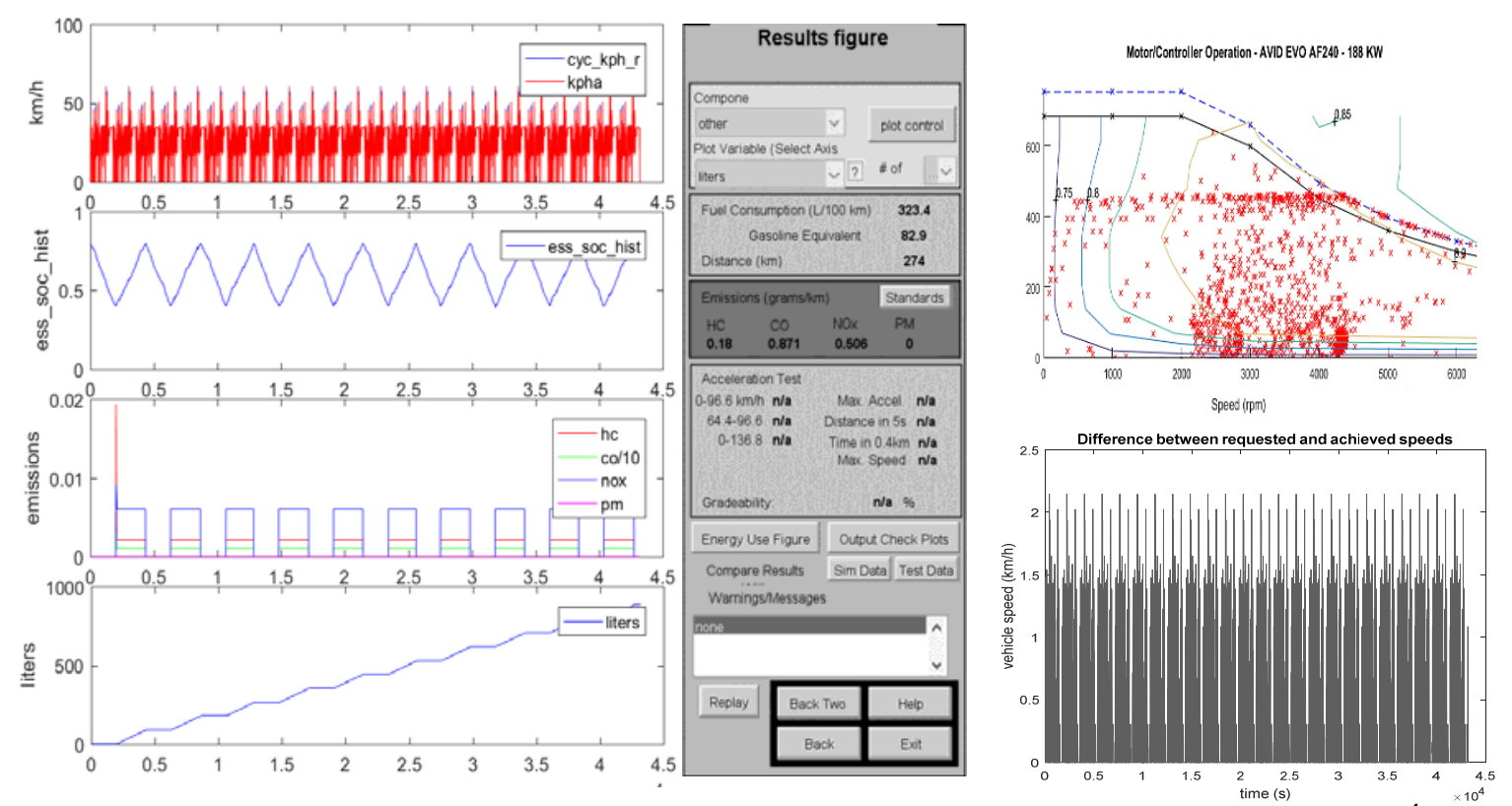

Fig. 12 On the left, results screen on Advisor, CNG vehicle. Notice that graphs have time on the $\mathrm{x}$-axle, in $\mathrm{s}^{\cdot 10^{-4}}$; on the top right, the motoring map (power mode); on the bottom right, the gap between imposed and achieved speed paths. The acceptable gap is $3.2 \mathrm{~km} / \mathrm{h}$. 
Table 7 Advisor simulation results for hybrid configuration with CNG fuel.

\begin{tabular}{|c|c|c|}
\hline \multicolumn{3}{|c|}{ Simulation results and derived data—GTHV Bus, CNG, GT100 kW, ESS $64.8 \mathrm{kWh}$} \\
\hline Drive-cycle & WHTC & limited $\left(a<1 \mathrm{~m} / \mathrm{s}^{2}\right)$ \\
\hline Drive-cycle repetitions & 24 & \\
\hline Total time & $12 \mathrm{~h}$ & \\
\hline Distance & $274 \mathrm{~km}$ & \\
\hline Energy out from electric motor & $541.25 \mathrm{kWh}$ & \\
\hline ESS charge-discharge cycles & 10 & \\
\hline Fuel consumption (volume) & $886 \mathrm{~L}$ & conversion at $\mathrm{CNG}$ storage conditions $\left(200 \mathrm{bar}, 15^{\circ} \mathrm{C}\right.$, \\
\hline Fuel consumption (mass) & $159 \mathrm{~kg}$ & $\rho=0.1796 \mathrm{~kg} / \mathrm{L})$ \\
\hline Fuel price & $0.96 € / \mathrm{kg}[45]$ & \\
\hline Total fuel expense & $153 €$ & \\
\hline Unit fuel cost & $0.56 € / \mathrm{km}$ & \\
\hline Emissions & & $\%$ of EURO VI limits (Fig. 2) \\
\hline $\mathrm{NO}_{\mathrm{x}}$ & $0.256 \mathrm{~g} / \mathrm{kWh}$ & $56 \%$ \\
\hline $\mathrm{CO}$ & $0.441 \mathrm{~g} / \mathrm{kWh}$ & $11 \%$ \\
\hline THC & $0.091 \mathrm{~g} / \mathrm{kWh}$ & $57 \%$ \\
\hline PM & $0 \mathrm{~g} / \mathrm{kWh}$ & $0 \%$ \\
\hline
\end{tabular}

Table 8 Advisor simulation results for hybrid configuration with LPG fuel.

\begin{tabular}{llc}
\hline \multicolumn{2}{l}{ Simulation results and derived data- } & GTHV Bus, LPG, GT100 kW, ESS $64.8 \mathrm{kWh}$ \\
\hline Drive-cycle & WHTC & \multicolumn{1}{l}{ limited $\left(a<1 \mathrm{~m} / \mathrm{s}^{2}\right)$} \\
\hline Drive-cycle repetitions & 24 \\
Total time & $12 \mathrm{~h}$ \\
Distance & $274 \mathrm{~km}$ & \\
Energy out from electric motor & $541.25 \mathrm{kWh}$ & \\
ESS charge-discharge cycles & 10 & \\
Fuel consumption (volume) & $307 \mathrm{~L}$ & \\
Fuel price & $0.67 € / \mathrm{kg}[46]$ & $\%$ of EURO VI limits (Fig. 2) \\
Total fuel expense & $206 €$ & $91 \%$ \\
Unit fuel cost & $0.75 € / \mathrm{km}$ & $11 \%$ \\
Emissions & & $57 \%$ \\
$\mathrm{NO}$ & $0.418 \mathrm{~g} / \mathrm{kWh}$ & $0 \%$ \\
$\mathrm{CO}$ & $0.441 \mathrm{~g} / \mathrm{kWh}$ & \\
THC & $0.091 \mathrm{~g} / \mathrm{kWh}$ & \\
PM & $0 \mathrm{~g} / \mathrm{kWh}$ & \\
\hline
\end{tabular}

while fuel volume requirement is lower. Table 8 resumes LPG vehicle simulation results.

Comparing Tables 7 and 8, CNG clearly emerges as the better fuel for this kind of application, as it provides the lower pollutants emissions and the lower per-km expenditure. Of course, it would need a larger and more technological tank, but as it is shown in Table 1, such solutions are available for these vehicles.

\subsection{Daily Cost: GTHV vs. ICE Comparative Analysis}

For a comparison, there have been considered two
ICE-diesel models, one is the Irisbus Cityclass 491 from Table 1, which is an old model, but still very diffused as a public transportation bus in the municipality of Rome. The second is a modern Mercedes Citaro Euro VI [47].

About costs from fuel, the CNG fuelled GTHV results in the most convenient solution, at the current fuel price in Italy, which for diesel is equal to $1.45 € / \mathrm{L}$ [48]. The LPG version instead proved more convenient than the Irisbus, but less than the Mercedes. 
Table 9 Economic comparison.

\begin{tabular}{lll}
\hline Fuel costs comparison & & \\
\hline & Fuel consumption & Daily cost (274 km/day) \\
\hline GTHV, CNG & $58.1 \mathrm{~kg} / 100 \mathrm{~km}$ & $153 € /$ day \\
GTHV, LPG & $112.2 \mathrm{~L} / 100 \mathrm{~km}$ & $206 € /$ day \\
Irisbus Cityclass 491, diesel & $51 \mathrm{~L} / 100 \mathrm{~km}$ & $203 € /$ day \\
Mercedes Citaro EuroVI, diesel & $38.7 \mathrm{~L} / 100 \mathrm{~km}$ & $154 € /$ day \\
\hline
\end{tabular}

These results seem to proof the unit cost benefit in advantage of GTHV (CNG) bus, but for this kind of vehicle it must also consider the ESS maintenance cost which is one of the most critical points in HEVs. Batteries suffer degradation after a long and frequent service and it must consider their periodic substitution. In this case, claimed battery life, from Table 3 , is 3,000 cycles, while its unit cost amounts to 500 $€ / \mathrm{kWh}$. To estimate the ESS daily cost it is possible to write:

$$
C_{E S S, \text { daily }}=\left(\frac{c_{\text {unit }} \cdot C A P}{L I F E} \cdot \text { frequency }\right) \quad[€ / \text { day }]
$$
where, frequency is the daily number of charge-discharge cycles (=10 cycles/day); CAP represents the capacity of the $\operatorname{ESS}(=64.8 \mathrm{kWh})$; LIFE is the number of cycles after which it could degrade $(=3,000$ cycles $) ; c_{\text {unit }}$ is the unit cost $(=500$ $€ / \mathrm{kWh})$.

Executing this calculus for the GTHV vehicle, it results the value of $108 € /$ day, to sum to the fuel costs.

This scenario compromises the GTHV economic convenience, as its less expensive version- $\mathrm{CNG}$ - reaches a daily cost equal to $261 €$, namely $69 \%$ more than the recent Mercedes, and 28\% higher than the Irisbus.

This analysis has been conducted with a conservative approach, as for example there has not been considered the ESS life extension benefit by the limitation in SOC operative range, as well as the probable unperfect matching between constructors' and real consumption data for the antagonist vehicles. Moreover, there have not been accounted for any government's incentives due to emissions reduction, and the simulated drive conditions are constantly at maximal load condition, while for a transit bus the real load varies a lot, due to passengers' hourly fluxes. Thus, there is a margin to lower the gap between GTHV and modern diesel bus costs, making the former more competitive.

\section{Conclusion and Future Approach}

The design of the gas turbine hybrid bus, has led to simulations results that reveal a substantial emission level reduction of the $\mathrm{CNG}$ fuelled version of the GTHV bus. This configuration meets the normative constraints by far. Data from simulations (Table 7) testify a fraction of Euro VI (2017 update) admissible limits (see Fig. 2) equal to $56 \%$ for $\mathrm{NO}_{\mathrm{x}}, 11 \%$ for $\mathrm{CO}$, $57 \%$ for $\mathrm{THC}$; corresponding respectively to $44 \%$, $89 \%, 43 \%$ savings. Moreover, the burning of gaseous fuels like CNG (and LPG) emits a negligible PM fraction.

The version fuelled with LPG does not reach the same savings in emissions, due to the worse $\mathrm{NO}_{\mathrm{x}}$ level (91\% of Euro VI limit), and at the same time it suffers higher operating costs. Therefore, although $\mathrm{CNG}$ version requires a larger, high-pressure tank (200 bar), it appears to be the best and more promising choice for implementing further studies and design about this kind of urban transportation vehicle.

The reduction in emissions of CNG GTHV is attributable on both the installed MT as the thermal PU, and series hybrid configuration adopted. The former, guarantees a better, continuous, more effective combustion if compared to a reciprocating ICE; the latter, lets the electric motor absorb the varying part of load, with the high efficiency of any electric machine, while the GT works at fixed point (rated power) to 
maximise its efficiency. However, this configuration implies the design of large electrical powertrain, that means higher costs for the electric storage system.

Unit transportation costs are approached in a comparative study between GTHV bus and two real models, an old Irisbus Cityclass 491, and a newer Mercedes Citaro, Euro VI certified. It emerges that, only for fuel's cost, the tested vehicle is the more economic (Table 9), with the expense of $153 € /$ day against 203 and $154 € /$ day from Irisbus and Mercedes respectively. However, adding ESS maintenance cost (substitution after a lifetime), the GTHV would require $261 € /$ day, well over its cited opponents.

From these calculations, it results that, if hybrid technology's environmental benefits are in evidence, its higher costs are still the most critical limit in HEVs development. The economic analysis has been carried out with a very conservative approach, thus it is expected to obtain more promising economic results in a more refined study.

In a future potential approach to a new GTHV bus design, it is recommended to observe and study the vehicle performances with attention on:

- ESS design. The battery pack could be slightly oversized to a major value respect to the actual 64.8 $\mathrm{kWh}$, to reduce both depth and frequency of charge-discharge cycles, to extend the ESS lifetime, reducing its daily-substitution costs. Of course, in this case would occur a higher installation investment, thus such balance must be optimized, with the help of more detailed studies and data about batteries behaviour.

- Control logic. A more refined control of energy fluxes could lead to further emissions and cost savings. It may test a Charge Sustaining (CS) logic to replace the actual Charge Depleting (CD) strategy. In this way, the frequency of ESS charge-discharge cycles could be minimized, and thermal PU can be downsized for supplying a reduced power surplus, as the SOC must not be increased but kept constant.

- GT downsizing. It has been noticed that a WHTC drive-cycle from real-drive condition requires the average power of about $40-50 \mathrm{~kW}$ to drive a 19 -tons heavy-duty bus like the tested one. This means that a smaller $(65 \mathrm{~kW})$ microturbine may be sufficient, for supplying enough power for both moving the vehicle and recharging/sustaining batteries, when SOC is at its minimum. This allows downsizing the thermal powertrain, with expected further savings in drivetrain building costs. Moreover, at mission equality, a turbine's downsizing should also provide a lower emitting vehicle (as datasheet's claimed emission factors for Capstone's C65 are lower than those by $\mathrm{C} 200$ ), but it would require a higher continuous ignition time, namely higher fuel consumption, given also that efficiency in turbines is generally a direct function of rated power. Finally, GT downsizing is another agent in ESS cycles frequency reduction, as the power surplus for battery recharge operations is reduced, consequently it would increase the ESS recharging time.

- Studies on vibrations and acoustic impact of an on-board generating microturbine system.

\section{References}

[1] European Environment Agency. 2017. EEA Report No. 13/2017. Air Quality in Europe, 2017 Report.

[2] International Energy Agency, World Energy Outlook Special Report. 2016. Energy and Air Pollution.

[3] World Health Organization. 2016. Ambient Air Pollution: A Global Assessment of Exposure and Burden of Disease.

[4] United States Environmental Protection Agency, EPA 450/2-80-071. 1980. Program to Prevent the Significant Deterioration of Carbon Monoxide, Ozone, Hydrocarbons, Nitrogen Dioxide, and Lead, p. 50.

[5] European Environment Agency. 2017. Chart-Emission of the Main Air Pollutants by Sector Group in the EEA-33.

[6] European Parliament, Initial Appraisal of a European Commission Impact Assessment. 2014. Reduction of Pollutant Emissions from Road Vehicles.

[7] Automotive Megatrend Magazine. 2016. The Future of Diesel Engines-And How OEMs Can Shape It.

[8] Transport Engineer. 2016. Next Generation Engines.

[9] Masuda, H., Higashitani, K., and Yoshida, H. 2006. Powder Technology Handbook, 3rd ed. CRC Press, p. 626.

[10] United States Environmental Protection Agency, EPA 
456/F-99-006R. 1999. Technical Bulletin, Nitrogen Oxides $\left(N O_{x}\right)$ : Why and How They Are Controlled.

[11] Lefebvre, A. H., and Ballal, D. R. 2010. Gas Turbine Combustion: Alternative Fuels and Emissions, 3rd ed. CRC Press, p. 370.

[12] Carslaw, D., Beevers, S., Westmoreland, E., Williams, M., Tate, J., Murrells, T., Stedman, J., Li, Y., Grice, S., Tsagakis, K., and Tsagakis, I. 2011. Trends in $N O_{x}$ and $\mathrm{NO}_{2}$ Emissions and Ambient Measurements in UK.

[13] Franco, V., Posada, F., German, J., and Mock, P. 2014. Real-World Exhaust Emissions from Modern Diesel Cars, The International Council on Clean Transportation, ICCT.

[14] Carslaw, D., and Rhys-Tyler, G. 2013. New Insights from Comprehensive On-Road Measurements of $\mathrm{NO}_{x}, \mathrm{NO}_{2}$ and $\mathrm{NH}_{3}$ from Vehicle Emission Remote Sensing in London, $U K$.

[15] Muncrief, R. 2015. Comparison of Real-World Off-Cycle $N O_{x}$ Emissions Control in Euro IV, V, and VI, The International Council on Clean Transportation, ICCT.

[16] Commission Regulation (EU) No 582/2011, CELEX 02011R0582. 2011. Implementing and Amending Regulation (EC) No. 595/2009 of the European Parliament and of the Council with Respect to Emissions from Heavy Duty Vehicles (Euro VI) and Amending Annexes I and III to Directive 2007/46/EC of the European Parliament and of the Council, 2017 reviewed.

[17] Ehsani, M., Gao, Y., and Emadi, A. 2009. Modern Electric, Hybrid Electric, and Fuel Cell Vehicles, CRC Press.

[18] Capata, R., and Sciubba, E. 2013. The Low Emission Turbogas Hybrid Vehicle Concept-Preliminary Simulation and Vehicle Packaging.

[19] Capata, R. 2016. Implementing a Hybrid Series Bus with Gas Turbine Device-A Preliminary Study.

[20] Capata, R., and Coccia, A. 2010. Procedure for the Design of a Hybrid-Series Vehicle and the Hybridization Degree Choice.

[21] Capata, R., and Lora, M. 2007. The LETHE Gas Turbine Hybrid Prototype Vehicle of the University of Roma 1: Drive Cycle Analysis of Model Vehicle Management Unit.

[22] Capata, R., and Sciubba, E. 2012. The LETHE (Low Emissions Turbo-Hybrid Engine) City Car of the University of Roma 1: Final Proposed Configuration.

[23] Capata, R., Cioffarelli, E., and Sciubba, E. 2003. A Gas Turbine-Based Hybrid Vehicle-Part II: Technological and Configuration Issues.

[24] Palumbo, C. 2017. Implementazione di veicoli ibridi per il trasporto pubblico urbano.

[25] GTT, Gruppo Torinese Trasporti, Parco Veicoli, IT available at: http://www.gtt.to. it/cms/risorse/gruppo/veicoli/parco_veicoli_tpl.pdf.

[26] Naunheimer, H., Bertsche, B., Ryborz, J., and Novak, K. 2011. Automotive Transmissions. Fundamentals, Selection, Design and Application, 2nd ed. Springer.

[27] EUR-Lex, Celex number 42013X0624(01). 2013. Regulation No. 49 of the Economic Commission for Europe of the United Nations (UN/ECE)-Uniform Provisions Concerning the Measures to Be Taken against the Emission of Gaseous and Particulate Pollutants from Compression-Ignition Engines and Positive Ignition Engines for Use in Vehicles, p. 159.

[28] Mercedes-Benz website at: https://www.mercedes-benz.com.cy/content/cyprus/mpc/ mpc_cyprus_website/enng/home_mpc/bus/home/buses world/update/news_2013/stuttgart.html.

[29] Volvo 7900 Hybrid, Brochure. Available at: http://www.volvobuses.co.uk/content/dam/volvo/volvo-b uses/markets/uk/our-offering/buses/7900-hybrid/docume nts/7900_HYBRID\%20brochure.pdf.

[30] Volvo 7900 Hybrid, specifications. Available at: http://www.volvobuses.co.uk/content/dam/volvo/volvo-b uses/markets/uk/our-offering/buses/7900-hybrid/docume nts/7900-HYBRID-Specifications.pdf.

[31] Zhu, Q., and Howe, D. 2006. Electrical Machines and Drives for Electric, Hybrid, and Fuel Cell Vehicles.

[32] Zeraoulia, M., Benbouzid, M., and Diallo, D. 2006. Electric Motor Drive Selection Issues for HEV Propulsion Systems: A Comparative Study.

[33] Pradhan, A., and Patil, S. 2016. Development of Sustainable Electric Motor for Electric Vehicle.

[34] AVID Technologies, Product Info. Available at: https://avidtp.com/product/evo-motors/.

[35] Cuppoletti, J. 2011. "Metal, Ceramic and Polymeric Composites for Various Uses." In Composite Cathode Material for Li-Ion Batteries Based on $\mathrm{LiFePO}_{4}$ System, edited by Molenda, J., Molenda, M.

[36] Soares, C. 2011. Microturbines Applications for Distributed Energy Systems, Butterworth-Heinemann.

[37] CAPSTONE Turbine Corporation, C65 Datasheet. Available at: http://www.regattasp.com/files/C65-ICHP\%20NATGAS $\% 20$ CARB.pdf.

[38] CAPSTONE Turbine Corporation, C200 Datasheet. Available at: http://www.regattasp.com/files/C200\%20High\%20NAT GAS.pdf.

[39] Boicea, V. 2013. Essentials of Natural Gas Microturbines, CRC Press, p. 47.

[40] CAPSTONE Turbine Corporation, MT Technology View. Available at: https://www.capstoneturbine.com/services.

[41] Pavri, R., and Moore, G. 2001. GE Energy Services, GER-4211. Gas Turbine Emissions and Control, p. 3. 
[42] NREL. 2013. Advisor Documentation. Available at: http://adv-vehicle-sim.sourceforge.net/advisor_doc.html.

[43] Advisor. Available at: https://sourceforge.net/projects/adv-vehicle-sim/.

[44] Scrosati, B., Garche, J., and Tillmetz, W. 2015. Advances in Battery Technologies for Electric Vehicles, Woodhead Publishing, p. 83.

[45] CNG Price (Feb. 2018). Available at: http://cngeurope.com/countries/italy/.

[46] LPG Price (Feb. 2018). Available at: https://www.globalpetrolprices.com/lpg_prices/.

[47] Informations by Mercedes-Benz UK website. Available at:

https:/www.mercedes-benz.co.uk/content/unitedkingdom $/ \mathrm{mpc} / \mathrm{mpc}$ _unitedkingdom_website/en/home_mpc/bus/ho $\mathrm{me} /$ buses_world/record_run/result/Promise_redeemed.ht $\mathrm{ml}$.

[48] Diesel Price (Feb. 2018). Available at: http://www.globalpetrolprices.com/diesel_prices/. 